\title{
Hepatoprotective Effectiveness Test Of Salam Leaf Extract In Anthracyclin-Induced Rats
}

\author{
Hariyento Halim ${ }^{1}$, Ermi Girsang ${ }^{2}$, Ali Napiah Nasution ${ }^{3 *}$ \\ $1,2,3,4$ Universitas Prima Indonesia \\ ${ }^{*}$ Corresponding Author: \\ Email: aallinafiah@gmail.com
}

\begin{abstract}
.
Cancer is the most often diagnosed disease in the world and the top cause of death. Doxorubicin is a widely used systemic therapy, although its efficacy is limited by dose-related toxicity, including haematological suppression, organotoxicity, and hepatotoxicity. Bay leaf is a commonly utilised plant in the community for treating and preventing many diseases because it includes secondary metabolites that are antioxidants such as phenolics, alkaloids, saponins, steroids, triterpenoids, and tannins. The purpose of this work is to characterise EEDS, identify its secondary metabolite content, and test its nephroprotective effect in doxorubicin-induced rats using SGPT and SGOT levels and liver histology. This is a laboratory experimental investigation using rats and comprises of treatment groups receiving $0.5 \%$ of CMC-Na, Nature E, or EEDS at doses of $100 \mathrm{mg} / \mathrm{kgBW}, 300 \mathrm{mg} / \mathrm{kgBW}$, or 500 $\mathrm{mg} / \mathrm{kgBW}$, respectively, followed by doxorubicin. The results indicated that EEDS had $21.64 \%$ water soluble material, $1.79 \%$ total ash, $9.98 \%$ water, $45.38 \%$ ethanol soluble extract, and $0.39 \%$ acid insoluble ash. EEDS included alkaloids, flavonoids, tannins, glycosides, saponins, and steroids/triterpenoids, as determined by phytochemical screening. EEDS doses of $100 \mathrm{mg} / \mathrm{kgBW}, 300 \mathrm{mg} / \mathrm{kgBW}$, and $500 \mathrm{mg} / \mathrm{kgBW}$ can significantly lower SGPT by 34\%; 52,46\%; 59,31\% and SGOT levels by 27,05\%; 43,96\%; 50,07\% and can improve the liver histopathology of doxorubicin-induced rats by reducing pyknotic degeneration, inflammatory cell infiltration, bleeding, steatosis and sinusoidal dilatation with an effective dose of $500 \mathrm{mg} / \mathrm{kgBW}$ with a significant difference with the doxorubicin group followed by $0.5 \% \mathrm{CMCNa}$. The key to bay leaf ethanol extract has hepatoprotective activity.
\end{abstract}

Keywords: Hepatoprotective, SGPT, SGOT, Doxorubicin, Bay leaf ethanol extract

\section{INTRODUCTION}

The status of the global burden of cancer worldwide is based on the GLOBOCAN, 2018 estimate report on cancer incidence and mortality produced by the International Agency for Research on Cancer, with a focus on geographic variability in 20 world regions. There will be approximately 18.1 million new cancer cases (17.0 million excluding nonmelanoma skin cancer) and 9.6 million cancer deaths (9.5 million excluding nonmelanoma skin cancer) in 2018. In both sexes, cancer lung cancer was the most commonly diagnosed cancer $(11.6 \%)$ of the total cases) and the leading cause of death from cancer (18.4\% of total cancer deaths), followed by female breast cancer $(11.6 \%)$, prostate $(7.1 \%)$, and colorectal cancer $(6.1 \%)$ for incidence and colorectal cancer $(9.2 \%)$, gastric cancer $(8.2 \%)$, and liver cancer $(8.2 \%)$ for mortality. Lung cancer is the most common cancer and the leading cause of cancer death among men, followed by prostate and colorectal cancer (for incidence) and liver and stomach 
cancer (for death). Among women, breast cancer was the most commonly diagnosed cancer and the leading cause of cancer death, followed by colorectal and lung cancer (for incidence), and vice versa (for death); Cervical cancer ranks fourth for incidence and mortality. The most commonly diagnosed cancers and the leading cause of cancer death, however, vary substantially by country and within each country depending on the level of economic development, associated social and lifestyle factors. It is noteworthy that high-quality cancer registration data, the basis for planning and implementing evidence-based cancer control programs, are not available in most lowand middle-income countries. The Global Initiative for the Development of Cancer Registry is an international partnership that supports better estimation, as well as the collection and use of local data, to prioritize and evaluate national cancer control efforts (Bray et al, 2018).

The cancer transition is most striking in developing countries, where the magnitude of the disease is paralleled by a changing profile of common cancer types. The repeated observation is that the continuing shift from cancer-related infection and poverty to cancer is already very common in the most developed countries (eg, in Europe, North America, and high-income countries in Asia and Oceania). These cancers are often ascribed to the so-called westernized lifestyle, but 3-5 different cancer profiles in each country and between regions suggest that marked geographic diversity still exists, with local risk factors persisting in populations at very high levels. different from the population. social and economic transition. This is illustrated by the stark differences in rates of infection-associated cancers, including cervical, gastric, and liver, observed in countries at opposite ends of the human developmental spectrum. The incidence of cancer in Indonesia (136.2/100,000 population) ranks 8 th in Southeast Asia, while in Asia it is $23 \mathrm{rd}$. The highest incidence rate in Indonesia for men is lung cancer, which is 19.4 per 100,000 population with an average 10.9 deaths per 100,000 population, followed by liver cancer at 12.4 per 100,000 population with an average death rate of 7.6 per 100,000 population. Meanwhile, the highest incidence rate for women is breast cancer, which is 42.1 per 100,000 population with an average death rate of 17 per 100,000 population, followed by cervical cancer at 23.4 per 100,000 population with an average death rate of 13.9 per 100,000 population. . Based on Riskesdas data, the prevalence of tumor/cancer in Indonesia showed an increase from 1.4 per 1000 population in 2013 to 1.79 per 1000 population in 2018. The highest cancer prevalence was in DI Yogyakarta province at 4.86 per 1000 population, followed by West Sumatra. 2.4779 per 1000 population and Gorontalo 2.44 per 1000 population (Kemenkes RI. 2019).

The function of the liver as a center for drug metabolism causes the liver to be most at risk for toxicity. Based on the FDA (Food and Drug Administration) report in the United States, there are more than 900 types of drugs, toxins and herbal preparations that have the potential to injure the liver and $20-40 \%$ of cases of liver failure are caused by drugs. Drug-induced liver disease can be intrinsic and 
idiosyncratic. Intrinsic reactions occur when the drug or its metabolites that damage the liver are predictable, reproducible and dose dependent, whereas idiosyncratic reactions are unpredictable and non-reproducible, and have a low incidence in individuals taking the drug. Idiosyncratic reactions can come from metabolic idiosyncrasy or immunoallergic reactions (Lewis, 2008; Barret et al, 2010 in Nirmala et al, 2012).

Radiation and chemotherapy are treatments that are widely used for cancer. Despite their antitumoral effects controlling both primary and metastatic tumors, both therapeutic modalities can produce toxicity to normal tissues and often, the associated side effects outweigh the clinical benefits and impair patients' quality of life (Lamas et al, 2015). Anthracycline Doxorubicin is a highly effective anti-neoplastic agent, which intercalates in DNA and inhibits topoisomerase II. Doxorubicin is one of the most common systemic treatments for improving several cancers in adults as well as children, including hematological and solid tumors. Unfortunately, the clinical efficacy of anthracyclines is hampered by dose-related toxicities, such as hematopoietic suppression and organotoxicity; although the most serious side effect is life-threatening cardiomyopathy, other organs are also involved, such as the liver, kidneys and pancreas (King and Perry, 2001; Lamas et al, 2015).

From time immemorial, plants have played a key role for the advancement of mankind as a source of extraordinary natural medicine. The complexity in formulating chemical-based drugs as well as their health-related side effects and very high costs have led researchers around the world to focus on medicinal plant research. Therefore, traditional medicine is a field that is still in great demand for research (Hasan, 2016). This is based on several things such as the need for compounds to overcome various diseases such as AIDS (Acquired Immunodeficiency Syndrome), cancer including as hepatoprotective (Armansyah et al, 2010). Some medicinal plants that have been researched and recognized as hepatoprotective are turmeric, bitter, temulawak, white ginger, noni, rosella petals, yellow turmeric and many other leaves that are beneficial for healing and preventing a disease. All these plants are known to contain high antioxidants, because antioxidants are needed to counteract free radicals which are one of the causes of liver damage (Tristanti et al, 2013 in Hasan, 2016).

In general, the biological effects caused by the use of anthracycline doxorubicin are the occurrence of apoptosis, necrosis, and autophagy (Tacar et al, 2013). The mechanism of action of Doxorubicin can be explained by the use of intravenous doxorubicin distributed in the body within 3-5 minutes, and can circulate up to 24-36 hours in the bloodstream. Doxorubicin and the main metabolite doxorubicinol will be bound by plasma proteins, then enter the cell by passive diffusion with high affinity for binding to the cytoplasmic proteasome. Doxorubicin has a high affinity for nuclear DNA (Deoxyribonucleic acid) when attached to the proteasome (Buchholz et al. 2002). This allows Doxorubicin to separate from the proteasome and bind to DNA. Doxorubicin then intercalates / inserts and is stable in DNA replication. The ability of Doxorubicin to insert not only in nuclear DNA but also 
in mitochondrial DNA, Doxorubicin interacting with DNA causes inhibition of macromolecular biosynthesis (Minotti et al, 2004).

Vitamin $\mathrm{E}$ has been recognized as an anti-atherogenic, anti-inflammatory and anti-free radical that can reduce the effects of tissue damage caused by oxidative stress due to free radicals, so vitamin $\mathrm{E}$ is useful in the treatment of liver cirrhosis, neurological, cardiovascular, and malignant diseases such as tumors and diseases. cancer. The hepatoprotective effect of Vitamin $\mathrm{E}$ is to protect cells from free radicals or oxidative stress. Tocotrienols are components of natural Vitamin $\mathrm{E}$ in addition to tocopherols, which are fat-soluble antioxidants that protect cell membranes from oxidative damage. Tocotrienols and tocopherols are combined ingredients to reduce the effects of free radicals, inhibit cancer growth, are cardioprotective, and premature aging (Hadi et al, 2018).Medicinal plants are a precious gift of nature that play an important role in the health care systems of developing countries and are a source of potent medicines for curing various diseases in the world. It plays an important role to maintain our health. Medicinal plants are believed to be much safer, the cost is much cheaper, the raw materials are easily obtained. Nowadays, the use of herbal products has become the main choice for people all over the world because it cures the treatment without any side effects. The World Health Organization (WHO) also recommends and recommends the use of traditional medicines to treat various diseases, but the safety aspect of using traditional medicines must be prioritized in the selection of traditional medicines (WHO, 2000).

One of the new plants that is widely used by the community to treat various diseases and their prevention is bay leaf (Syzygium polyanthum (Wight.) Walp.) which is a species of the Myrtaceae family. Apart from being an ingredient in cooking, bay leaves are also known as traditional medicine. A number of studies have shown that the content of secondary metabolites that are antioxidants in it such as phenolics, alkaloids, saponins, steroids, terpenoid tannins in bay leaves are able to detoxify the body, so it has the potential to treat acid disease. uric acid, lowers cholesterol levels, lowers high blood pressure (Verawati et al, 2017), acetylcholinesterase inhibitory, prevention of plaque on teeth (Ismail and Ahmad, 2019), Flavonoids provide antioxidant effects that are very beneficial to prevent cancer and provide some protection for diabetes and atherosclerosis. (Sani et al, 2014). Many natural flavonoids play an important role in the prevention of diabetes (Jack, 2012). A number of studies have been conducted to demonstrate the hypoglycemic effect of flavonoids using different experimental models, the result is that plants containing flavonoids have been shown to have beneficial effects against diabetes mellitus, both through the ability to reduce glucose absorption and by increasing glucose tolerance (Brachmachari, 2011). Bay leaves are very effective as an ingredient in the treatment of haemorrhoids, diarrhea, gastric disorders (Silalahi, 2017). Antioxidants are needed to protect body cells from oxidative damage, prevent various degenerative diseases such as cancer, cardiovascular disease, cataracts, diabetes, Alzheimer's and Parkinson's (Blanco, 2013 in Verawati et al, 2017), 
the content of flavonoids, alkaloids and tannins in leaf extracts. Salam is useful as an inhibitor of bacterial growth (Tammi et al, 2018). Based on the background of cancer whose incidence continues to increase every year, chemotherapy drugs always cause cytostatic toxicity such as hepatotoxicity, high antioxidant content in bay leaf (Syzygium polyanthum (Wight.) Walp.) according to several studies capable of acting as a cytoprotectant, The researchers wanted to prove the hepatoprotective ability of the ethanolic extract of bay leaf (EEDS) (Syzygium polyanthum (Wight.) Walp.) by observing changes in liver enzymes and histology of liver tissue in adult male rats induced by hepatotoxicity with Anthracycline Doxorubicin.

\section{LITERATURE REVIEW}

\subsection{Biology of Bay Leaf (Syzygium polyanthum (Wight.) Walp.)}

Indonesia is a tropical country that has biodiversity, one of which is the diversity of medicinal plants. Based on the family group, there are 203 families of medicinal plants. In general, there are 22 families that have more than 20 medicinal plant species and another 181 families have less than 20 species. The Asteraceae family has 40 species (Zuhud, 2008). According to the BBPP (Agricultural Training Center) (2012) there are 9,600 known species of medicinal plants in Indonesia, but only about 200 species have been used as raw materials for the traditional medicine industry and only $4 \%$ can be cultivated. One of the biopharmaceutical commodities that is not widely known is bay leaf or known as Syzygium polyanthum (Wight.) Walp. Synonyms of bay leaf include Eugenia polyantha Wight (1831), Eugenia nitida Duthie (1878), Eugenia balsamea Ridley (1922).

\subsection{The content of chemical compounds in bay leaves.}

Several studies have revealed the phytochemical components of Syzygium polyanthum, but most of these studies have focused on the leaf parts of the plant. An initial phytochemical screening study conducted by Kusuma et al, (2017) revealed that the unripe leaves and fruits of Syzygium polyanthum contain carbohydrates, tannins, alkaloids, steroids, triterpenoids, and flavonoids, while the ripe fruits contain saponins, carbohydrates, tannins. , alkaloids, triterpenoids, and flavonoids. In fact, several studies have measured total phenolics and total flavonoids in various types of extracts from the bark and leaves of Syzygium polyanthum. Lelono et al, (2009) found that the methanol-water extract from the bark of Syzygium polyanthum had the largest total phenolic content (TPC) compared to the methanol and water extracts when measured as equivalents of catechins and gallic acid. In contrast, the methanol extract from the bark of Syzygium polyanthum showed the highest total flavonoid (TFC) content, when measured as rutin and flavonol equivalents compared to the methanol-water and aqueous extracts.

When the TPC of Syzygium polyanthum leaves was compared with the bark of Syzygium polyanthum from previous studies, the TPC of the former was found to be lower than the latter (Lelono et al, 2009; Ismail et al, 2017 in Ismail et al, 2019) . 
Based on research by Liliwirianis et al., (2011) bay leaves contain alkaloids, saponins, steroids, phenolics, flavonoids. Based on research by Pinatih et al., (2011) bay leaves show the presence of flavonoid, terpenoid and phenolic compounds. The methanol extract of bay leaves contains a lot of flavonoids and phenols. It is known that the flavonoid content is $14.87 \mathrm{mg}$ equivalent to quercetin/100 g extract. The results of the analysis using High Performance Liquid Chromatography (HPLC) identified phenol group compounds, namely caffeic acid and gallic acid (Har \& Ismail, 2012). According to the Indonesian Herbal Pharmacopoeia (2009), bay leaves contain a total flavonoid not less than $0.40 \%$ which is calculated as quercetin (Rizki and Hariandja, 2015).

\subsection{Simplified Overview}

Simplicia is a natural ingredient that is used for medicine and has not undergone any process changes, and unless otherwise stated, is generally a dried material. Medicinal plant simplicia is a raw material for the process of making extracts, either as medicinal ingredients or products. Based on this, simplicia is divided into three groups (Istiqomah, 2013), namely:

\section{Vegetable Simplicia}

Vegetable simplicia is simplicia in the form of whole plants, plant parts and plant exudates. Plant exudates are cell contents that spontaneously come out of plants or cell contents are removed from their cells in a certain way or substances that are separated from plants in a certain way that are still not in the form of pure chemical substances.

2. Animal Simplicia

Animal simplicia is a complete animal simplicia, animal parts, or not yet in the form of pure chemical substances.

\section{Mineral Simplicia}

Mineral simplicia is simplicia originating from the earth, whether it has been processed or not, not in the form of pure chemical substances

\subsection{Doxorubicin}

The United States Food and Drug Administration (FDA = Food and Drug Administration) has approved 132 anticancer drugs, which are the most widely used anthracyclines. Considered the mainstay of therapy for decades, conventional anthracycline-containing regimens have shown benefits in terms of response rates, time to disease progression, and overall survival (Winer et al, 2001; Carvalho et al, 2009).

Doxorubicin which is an anthracycline chemotherapy drug class, is one of the important anticancer agents in clinical use to slow and inhibit the growth of cancer cells, especially in breast, endometrial, ovarian, testicular, thyroid, liver, lung, soft tissue sarcomas and cancers. several cancers in children, including neuroblastoma, Ewing's sarcoma, osteosarcoma, hematological cancer, rhabdomyosarcoma (Chu, 2009). Despite its wide clinical use, the mechanism of action of Doxorubicin remains under intense debate. Increasing evidence supports the view that drugs, this can be a double edged sword. Indeed, injury to untargeted tissues often complicates cancer treatment by limiting the therapeutic dose of Doxorubicin and reducing the patient's 
quality of life during and after Doxorubicin treatment. The literature indicates that the heart is the preferred target of Doxorubicin toxicity. However, these anticancer drugs also affect other organs such as the brain, kidneys, and liver (Carvalho et al, 2009). In general, doxorubicin is used in combination with other anticancer agents (eg cyclophosphamide, cisplatin, and 5-FU) and clinical activity is increased in combination compared with single use (Chu, 2009).

The first two anthracyclines were isolated from the pigment-producing Streptomyces peucetius in the early 1960s and were named Doxorubicin (DOX) and daunorubicin (DNR). Drugs containing aglyconic and sugar sugars. Aglycones consist of a tetracyclic ring with adjacent quinone-hydroquinone groups, a methoxy substituent and a short side chain with a carbonyl group. The sugar, called daunosamine, is attached by a glycosidic bond to one of the rings and consists of a 3-amino-2,3,6trideoxy-L-fucosyl group. The only difference between these two molecules is the fact that the DOX side chain ends with a primary alcohol, while the DNR chain ends with a methyl group. Although widely used, the cytotoxic effects of anthracyclines are multidirectional, cardiotoxicity is the most well-known side effect. In order to find a better anthracycline, about 2000 analogues were produced with some chemical modification or substitution and/or conjugation introduced in the tetracyclic ring, side chain or amino-sugar. For example, epirubicin (EPI) is a semisynthetic derivative of DOX obtained by axial-toequatorial epimerization of the hydroxyl group in the carbon of daunosamine. This positional change has little effect on the mode of action and spectrum of antineoplastic activity of EPI compared to DOX but it does introduce pharmacokinetic and metabolic changes such as increased volume of distribution and consequent increase in total body clearance or shorter terminal half-life.

Doxorubicin is one of the most potent antineoplastic drugs prescribed alone or in combination with other agents, the rest of its class of compounds having the broadest spectrum of activity. Indeed, Doxorubicin is used in the treatment of solid tumors and haematological malignancies, including breast, bile duct, prostate, uterine, ovarian, gastric and liver tumors, childhood solid tumors, osteosarcoma and soft tissue sarcoma, Kaposi's sarcoma, and myeloblastic and lymphoblastic leukemia. acute and Wilms tumor (Danesi et al, 2002; Gruber et al, 2004; Breslow et al, 2004 in Carvalho et al, 2009).Many studies have linked the antitumor activity of Doxorubicin with its ability to intercalate into the DNA helix and/or bind covalently to proteins involved in DNA replication and transcription. The interactions result in inhibition of DNA, RNA, and protein synthesis, which ultimately leads to cell death.

Recently, Ashley and Poulton, using a new method utilizing the fluorescent DNA dye PicoGreen, found that anthracyclines not only intercalate into nuclear DNA but also mitochondrial DNA (mtDNA) (Cutts et al, 1996; Cutts et al, 2005; Ashley and Poulton, 2009 in Carvalho et al, 2009). Some studies classify Doxorubicin as a topoisomerase II poison. The topoisomerase group of enzymes modifies the topology of DNA without changing its structure and sequence and catalyzes the breakdown of 
DNA for transcription and replication, which involves the process of cleaving one strand of the DNA duplex and passing the second duplex through this transient cleavage. The intermediate formed is called a 'cleavable complex' (Swift et al, 2006). Doxorubicin poisons the cleavage complex, inhibiting re-ligation of the truncated duplex, the lesion producing DNA double-strand break (DSB). Failure to repair DSB DNA results in the apoptotic response (Liu et al, 1983; Tewey et al, 1984 in Carvalho et al, 2009).

\section{METHODS}

This study used an experimental method, namely to determine the effect of the relationship between the independent variable and the dependent variable (hepatoprotective activity) with the stages of sample preparation, sample identification, characterization of simplicia powder, phytochemical screening of simplicia powder, extract manufacture, extract characterization, extract phytochemical screening, preparation of test animals. , testing of hepatoprotector activity in male rats which included examination of the activity of Alanine Transferase (ALT), Aspartate Transferase (AST) and liver histopathology and data processing. $0.5 \% \mathrm{Na}$ CMC was given as a solvent control in the negative control group and the positive control group was given Vitamin $\mathrm{E}$ at a dose of $1 \% \mathrm{bw}$ as a comparison of the hepatoprotective effect of the extract group. The data were analyzed using the SPSS 22.0 program using the ANOVA test.

\section{RESULT AND DISCUSSION \\ 4.1 Physical Quality of Extract \\ 1. Organoleptic}

The results of the manufacture of bay leaf ethanol extract which was carried out by maceration method using $96 \%$ ethanol solvent, namely $1000 \mathrm{~g}$ of bay leaf simplicia powder macerated with $10 \mathrm{~L}$ of ethanol resulted in 123.5 grams of bay leaf ethanol extract with an extract yield of $12.35 \%$. The resulting extract is dark green (blackish green) with a distinctive odor, has a thick texture and tastes bitter and chelating. The results of research conducted by Widyastuti and Putranti (2019) showed that bay leaves macerated with $96 \%$ ethanol produced ethanolic extract of bay leaves which had a thick organoleptic, blackish green, distinctive odor and had a bitter and chelating taste.

\section{Viscosity Value}

Viscosity is the resistance or inability of a material to flow when subjected to a drag force. The results of the viscosity tests carried out on the ethanolic extract of bay leaves can be seen in Table 1 below

Table 1. Test Results of Viscosity Measurement of Salam Leaf Ethanol Extract

\begin{tabular}{|c|c|c|}
\hline Speed RPM & Data (mpa's) & Persen (\%) \\
\hline 12 & 2497 & $99,9 \%$ \\
\hline
\end{tabular}




\begin{tabular}{|c|c|c|}
\hline 30 & 999 & $99,9 \%$ \\
\hline 60 & 499,5 & $99,9 \%$ \\
\hline
\end{tabular}

Viscosity testing was carried out using the NDJ-8S viscometer. The spindle used is spindle number 2 with 3 different RPMs, namely 12, 30 and 60. From the table above, it can be seen that the three RPMs used show the same percentage value of $99.9 \%$, where this result meets the criteria for the rotor range table. which is close to $100 \%$. From the table, it can be seen that the viscosity value of the ethanolic extract of bay leaves is 2497 mpas. This large viscosity value is due to the texture of the ethanolic extract of bay leaves which is thick and difficult to pour.

\section{PH value}

Determination of the $\mathrm{pH}$ value of the ethanolic extract of bay leaves was carried out using a $\mathrm{pH}$ meter. The results of testing the $\mathrm{pH}$ of the bay leaf ethanol extract can be seen in Table 2 below.

Table 2. PH Test Results of Salam Leaf Ethanol Extract

\begin{tabular}{|c|c|c|c|}
\hline Measurement1 & Measurement 2 & Measurement 3 & Average \pm SD \\
\hline 5,9 & 5,8 & 5,8 & $5,83 \pm 0,06$ \\
\hline
\end{tabular}

From the table above, it can be seen that the measurement of the $\mathrm{pH}$ of the ethanolic extract of bay leaves was repeated 3 times with an average value of 5.83 . The $\mathrm{pH}$ value is the degree of acidity used to determine the level of acidity or alkalinity possessed by a preparation. The $\mathrm{pH}$ value obtained is included in the category of acidic $\mathrm{pH}$ where the $\mathrm{pH}$ value is less than 7 .

\subsection{Extract Characterization}

From the result of this study, it can be seen that the results of the determination of the water content of the ethanolic extract of bay leaf obtained were $9.98 \%$. This level meets the requirements stated in the monograph for bay leaves, which is not more than $10 \%$. Determination of water content is carried out to determine how much water content is in the extract related to purity and microbial contamination that is likely to occur if the water content is too large (Yulianti et al, 2014). Ethanol extract of bay leaf can have a good level of stability if it has a water content of less than $10 \%$ because at that level it is proven to be able to inhibit the growth of fungi and molds so as to improve the quality of the extract obtained (Zainab et al, 2016). Determination of the juice content of an extract of natural ingredients aims to provide an initial description of the amount of content contained in the extract. According to the Indonesian Herbal Pharmacopoeia (2008), the water soluble extract content of bay leaves is not less than $7.4 \%$ and the water soluble extract content obtained is $21.64 \%$.

This shows that the levels obtained still meet the requirements stated in the monograph. Determination of water soluble extract content aims to estimate how much polar chemical compounds such as organic acids, gums, dyes, enzymes and glycosides contain. The ethanol soluble extract content of the ethanolic extract of bay leaves obtained was $45.38 \%$ and this level still met the requirements stated in the Indonesian 
Herbal Pharmacopoeia (2008), which was not less than 7.8\%. Determination of ethanol soluble extract content aims to estimate the amount of chemical compounds that are polar-nonpolar such as saponins, a little fat, tannins, glycosides, flavonoids, chlorophyll, and steroids dissolved during the extraction process (Saifudin et al, 2011). The high content of soluble ethanol extract was caused by the use of $96 \%$ ethanol as solvent in the maceration process so that polar-non-polar compounds were more attracted.

The total ash content of the ethanolic extract of bay leaves obtained was $1.79 \%$ where this level still met the requirements stated in the monograph, which was not more than 5.5\%. Ash is an inorganic substance left over from the combustion of an organic material. The ash content and its composition in foodstuffs depend on the type of material and the method of making the ash. The ash content of a material is closely related to the mineral content of the material. Minerals contained in a material can be of two kinds of salts, namely organic salts (such as malic acid, oxalic acid, acetic acid, and pectic) and inorganic salts (such as phosphate, carbonate, chloride, sulfate, nitrate and alkali metal salts), or can also be in the form of minerals that are formed into complex organic compounds (Saragih, 2014; Kartikasari et al, 2014). The last test was carried out to determine the amount of acid insoluble ash content and the results obtained were $0.39 \%$ where this result still met the requirements stated in the monograph for bay leaves, which was not more than $1.8 \%$. Testing the acid insoluble ash content using ash obtained from the determination of the total ash content with the addition of $\mathrm{HCl}$ aims to determine whether there is contamination originating from external factors such as sand from the soil and dust attached to the drying time (Suharti et al, 2017). The presence of low acid insoluble ash content indicates the presence of sand or other impurities in a low state (Kartikasari et al, 2014).

\subsection{Phytochemical Screening}

Phytochemical screening is carried out as an early stage of identification to determine the class of bioactive compounds or also called secondary metabolites contained in simplicia or extracts and as an important step in determining the potential activity of these preparations as drugs (Simaremare, 2014). Phytochemical screening is a preliminary stage that can provide an overview of the content of certain chemical compounds that may be present in the natural materials to be used. The choice of solvent and extraction method is very important that can affect the phytochemical screening process due to the selection of an inappropriate solvent that allows the desired active compound not to be properly and completely attracted (Simaremare, 2014). glycosides, alkaloids, tannins, saponins, flavonoids and steroids/triterpenoids.In the glycoside test, a positive reaction was indicated by the formation of a purple ring at the liquid boundary after the addition of sulfuric acid. Glycosides are compounds that contain sugar and non-sugar components so that they can be attracted to solvents such as ethanol. Glycosides are composed of glycone and aglycone parts which include 
alcoholic, phenolic, isothiocyanate, flavonoid and steroid compounds (Puspitasari, 2013; Padmasari, 2013).

Positive results on the alkaloid test using the Mayer test are indicated by the presence of a yellow precipitate. This is probably because the nitrogen in the alkaloids will react with the metal ion $\mathrm{K}+$ from potassium tetraidomercurate (II) to form a precipitated potassium-alkaloid complex. Positive results of alkaloids in the Bouchardat test were indicated by the formation of a blackish brown precipitate. In making Bouchardat reagent, the reaction between iodine and I- from potassium iodide produces I3- which is brown. In this test, $\mathrm{K}+$ ions will form coordinate covalent bonds with nitrogen in the alkaloids to form a precipitated potassium-alkaloid complex. The positive results of the alkaloid test in the Dragendorff test were indicated by the formation of a brick red precipitate. The manufacture of Dragendorff bismuth nitrate reagent is dissolved with HCL solution so that no hydrolysis reaction occurs because bismuth salts are easily hydrolyzed to form bismuth ions. Then the acid is added so that the $\mathrm{Bi} 3+$ ions remain in the solution. The Bi3+ ion from bismuth nitrate will react with potassium iodide to form a black precipitate of Bismuth (III) iodide which will then dissolve in excess potassium iodide to form tetraiodobismuthate. In this test nitrogen is used to form a coordinate covalent bond with $\mathrm{K}+$ (Marpaung et al, 2017).

Positive results in the tannin test were indicated by the formation of a greenblack color after the addition of $\mathrm{FeCl} 3$. Tannins are a class of phenolic compounds that tend to dissolve in water so they are more polar. The formation of a green-black color in the extract after the addition of $\mathrm{FeCl} 3$ was due to one of the hydroxyl groups present in the tannin compound reacting with $\mathrm{Fe} 3+$ ions to form a complex compound. In this addition, the tannin group will produce a blue-black color which will then be condensed to produce a green-black color (Sangi et al, 2008).Saponins are compounds that contain glycosyl groups which act as polar groups and steroid and triterpenoid groups which act as nonpolar groups. Saponin compounds are surface active due to the presence of polar and non-polar groups so that when shaken with water they will form micelles, where the polar groups will face out while the non-polar groups will face inward. Positive results for the presence of saponins are indicated by the formation of foam due to the formation of micelles (Puspitasari, 2013).Flavonoids are polyphenolic compounds that have a number of hydroxy groups so they tend to be polar. The ethanolic extract of bay leaf is dissolved in hot water and then boiled because most of the flavonoid groups can be dissolved in hot water.

Positive results from the flavonoid test are indicated by the formation of a red color with the addition of $\mathrm{HCl}$ and magnesium powder causing the reduction of the existing flavonoid compounds to form flavilium salts (Wilapangga and Sari, 2018; Marpaung 2017).Triterpenoids are composed of a long chain of C30 hydrocarbons which makes this compound non-polar. Triterpenoid compounds that have a cyclic structure in the form of alcohols, aldehydes or carboxylic acids with - $\mathrm{OH}$ groups make these compounds semipolar. The results of the tests carried out on the steroid and 
triterpenoid compounds showed positive results with the formation of a blue green color due to the ability of these compounds to form colors in the presence of concentrated sulfuric acid in acetic anhydride solvent where the steroid/triterpenoid compound group was oxidized through the formation of conjugated double bonds (Sangi, 2013).

4.4 Levels of SGPT / ALT (Serum Glutamic Pyruvic Transaminase / Alanine aminotransferase)

Serum glutamate pyruvate transaminase (SGPT) or also called alanine aminotransferase (ALT) is an enzyme found in liver cells and is widely used as a diagnosis of liver damage. This enzyme is also found in trace amounts in heart, kidney and skeletal muscle.

Table 3. Measurement Results of SGPT/ALT . Levels

\begin{tabular}{|c|l|c|}
\hline No & \multicolumn{1}{|c|}{ Group } & Average of SGPT (U/L) \pm SD \\
\hline 1 & Normal & $82,33 \pm 32,87^{\mathrm{c}}$ \\
\hline 2 & Induced Doxorubicin+ Na-CMC 0,5\% & $268,67 \pm 56,50^{\mathrm{a}, \mathrm{b}}$ \\
\hline 3 & Induced Doxorubicin + Vitamin E 1\% BB & $103,00 \pm 18,52^{\mathrm{c}}$ \\
\hline 4 & Induced Doxorubicin + EEDS 100 mg/kg BB & $177,33 \pm 39,95^{\mathrm{a}}$ \\
\hline 5 & Induced Doxorubicin + EEDS 300 mg/kg BB & $128,00 \pm 28,61^{\mathrm{c}}$ \\
\hline 6 & Induced Doxorubicin + EEDS 500 mg/kg BB & $109,33 \pm 7,02^{\mathrm{c}}$ \\
\hline
\end{tabular}

The results showed that the levels of SGPT in the doxorubicin group followed by $0.5 \%$ $\mathrm{Na} \mathrm{CMC}$ had a significant difference with the normal group and the doxorubicin group followed by vitamin $\mathrm{E}$ administration $(\mathrm{p}<0.05)$ but had no significant difference with the group given doxorubicin. doxorubicin followed by administration of EEDS at a dose of $100 \mathrm{mg} / \mathrm{kg} \mathrm{BW}(\mathrm{p}>0.05)$.

The doxorubicin administration group accompanied by the administration of EEDS with various doses showed a difference and no difference with the doxorubicin group followed by $0.5 \% \mathrm{Na}-\mathrm{CMC}$ administration. The doxorubicin administration accompanied by EEDS at a dose of $100 \mathrm{mg} / \mathrm{kg}$ BW showed no difference with the doxorubicin group followed by $0.5 \% \mathrm{Na}$ CMC administration and the doxorubicin group followed by vitamin $\mathrm{E}$ administration $(\mathrm{p}>0.05)$ but there were differences with the normal group. $(\mathrm{p}<0.05)$. Along with the increase in the dose of EEDS administration, namely $300 \mathrm{mg} / \mathrm{kg} \mathrm{BW}$ and $500 \mathrm{mg} / \mathrm{kg} \mathrm{BW}$, there was a difference with the doxorubicin group followed by $0.5 \% \mathrm{Na}-\mathrm{CMC}$ administration $(\mathrm{p}<0.05)$ but there was no difference with the normal and normal groups. doxorubicin group was followed by vitamin $\mathrm{E}(\mathrm{p}>0.05)$.

\subsection{Levels of SGOT / AST (Serum Glutamic Oxaloacetic Transaminase / Aspartate aminotransferase)}

SGOT (Serum glutamic oxaloacetic transaminase) or also known as AST (Aspartate aminotransferase) is an enzyme that plays a role in converting aspartate and 
-ketoglutarate into oxaloacetate and glutamate. This enzyme is found in liver parenchyma cells and can also be found in the heart, skeletal muscle and kidneys. The results of the measurement of SGOT/AST levels can be seen in Table 4 below.

Table 4. Results of Measurement of SGOT/AST

\begin{tabular}{|c|l|c|}
\hline No & \multicolumn{1}{|c|}{ Group } & $\begin{array}{c}\text { Average of SGOT (U/L) } \pm \text { SD } \\
\text { Level }\end{array}$ \\
\hline 1 & Normal & $85,33 \pm 9,29^{\mathrm{c}}$ \\
\hline 2 & Induced Doxorubicin+ Na-CMC 0,5\% & $240,33 \pm 66,52^{\mathrm{a}, \mathrm{b}}$ \\
\hline 3 & Induced Doxorubicin+ Vitamin E 1\% BB & $101,33 \pm 8,62^{\mathrm{c}}$ \\
\hline 4 & Induced Doxorubicin+ EEDS 100 mg/kg BB & $175,33 \pm 33,86$ \\
\hline 5 & Induced Doxorubicin+ EEDS 300 mg/kg BB & $134,67 \pm 32,02^{\mathrm{c}}$ \\
\hline 6 & Induced Doxorubicin+ EEDS 500 mg/kg BB & $120,00 \pm 8,54^{\mathrm{c}}$ \\
\hline
\end{tabular}

From the table above, it can be seen that there was a significant difference between the doxorubicin group followed by $0.5 \% \mathrm{CMC} \mathrm{Na}$ administration and the normal group and the doxorubicin group with vitamin E, EEDS at a dose of $300 \mathrm{mg} / \mathrm{KgBW}$ and a dose of $500 \mathrm{mg} / \mathrm{kgBW}(\mathrm{p}<0.05)$, but there was no significant difference with the doxorubicin group followed by EEDS at a dose of $100 \mathrm{mg} / \mathrm{kgBW}(\mathrm{P}>0.05)$. The doxorubicin group followed by EEDS at a dose of $100 \mathrm{mg} / \mathrm{kgBW}$ had no significant difference with the normal group and all treatment groups. The treatment group given doxorubicin accompanied by EEDS at a dose of $300 \mathrm{mg} / \mathrm{kgBW}$ and EEDS at a dose of $500 \mathrm{mg} / \mathrm{kgBW}$ showed a difference with the doxorubicin group with CMC Na $0.5 \%$ (p $<0.05$ ) but did not have a significant difference with the normal group and the doxorubicin group with vitamin $\mathrm{E}(\mathrm{P}>0.05)$.

\subsection{Liver histopathology}

To determine the effect of doxorubicin on the liver, it can be seen in the histopathology of the liver. Liver histopathology results can be seen in Figure 4.3 below.
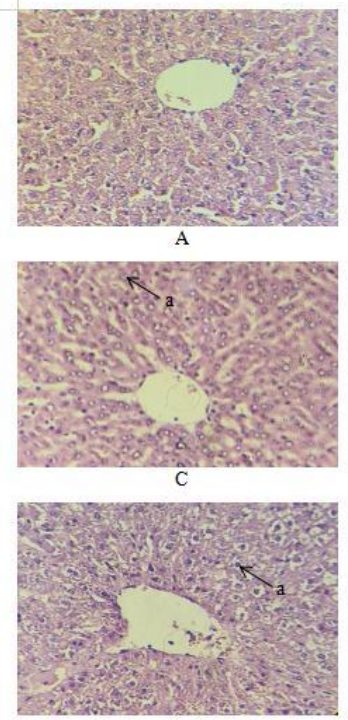

E

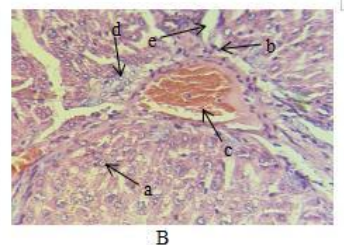

B
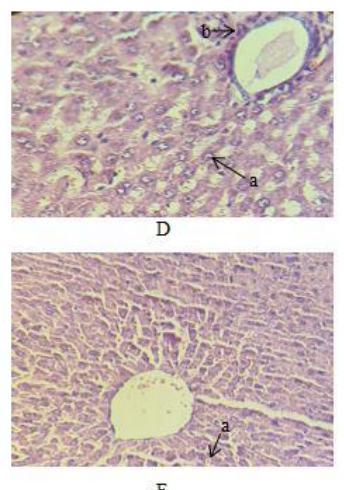
From the picture above, it can be seen the histological picture of the liver in the normal group and the treatment group given doxorubicin with $0.5 \% \mathrm{CMC}-\mathrm{Na}$, vitamin $\mathrm{E}$ and EEDS with varying doses. The results showed that the normal group showed a normal histological picture of the liver that was not damaged. In the doxorubicin group with $0.5 \% \mathrm{CMC}-\mathrm{Na}$, it showed changes in liver histology in the form of pyknotic degeneration, inflammatory cell infiltration, hemorrhage, edema, sinusoidal dilatation. Zhao et al (2012) reported that administration of doxorubicin was able to cause damage to the liver architecture such as bleeding (hemorrhage), inflammatory cell infiltration around hepatocytes and necrosis. The results of another study showed that mice treated with doxorubicin showed hepatocyte necrosis, atypia and mitotic rate in some hepatocytes, as well as mild focal chronic lobular inflammation, accumulation of inflammatory cells in hepatocytes, mitochondrial vacuolization and swelling, weak pyknotic nuclei, thickening serous, severe hyperemia and the presence of widening of the intercellular space (Saad et al, 2001; Kuzu et al, 2019).

\section{CONCLUSIONS AND RECOMMENDATION}

\subsection{Conclusion}

a. Ethanol extract of bay leaf (EEDS) has met the characterization requirements, namely water soluble extract content of $21.64 \%$ (> 7.4\%), total ash content of $1.79 \%(<5.5 \%)$, water content of $9.98 \%(<10 \%)$, ethanol soluble extract content of $45.38 \%(>7.8 \%)$ and acid insoluble ash content of $0.39 \%(<1.8 \%)$.

b. The results of phytochemical screening of bay leaf ethanol extract (EEDS) contain alkaloids, flavonoids, tannins, glycosides, saponins and steroids/triterpenoids.

c. Bay leaf ethanol extract (EEDS) has hepatoprotective activity in in vivo studies.

d. Ethanol extract of bay leaf (EEDS) doses of $100 \mathrm{mg} / \mathrm{kgBW}, 300 \mathrm{mg} / \mathrm{kgBW}$ and 500 $\mathrm{mg} / \mathrm{kgBW}$ can reduce SGPT and SGOT levels in hepatotoxic rats due to doxorubicin induction.

e. Ethanol extract of bay leaf (EEDS) doses of $100 \mathrm{mg} / \mathrm{kgBW}, 300 \mathrm{mg} / \mathrm{kgBW}$ and 500 $\mathrm{mg} / \mathrm{kgBW}$ could improve the liver histopathology of doxorubicin-induced rats but not better than vitamin $\mathrm{E}$ (positive control).

f. The dose of bay leaf extract which was effective in reducing the levels of SGPT and SGPOT and improving the liver histology of doxorubicin-induced rats was a dose of $500 \mathrm{mg} / \mathrm{kgBW}$.

g. Vitamin E (positive control) was more effective than bay leaf ethanol extract (EEDS) at doses of $100 \mathrm{mg} / \mathrm{kgBW}, 300 \mathrm{mg} / \mathrm{kgBW}$ and $500 \mathrm{mg} / \mathrm{kgBW}$.

\subsection{Recommendation}

In future research, it is better to use other parameters such as MDA, GSH, GPx. 


\section{REFERENCES}

[1] Armansyah, T.R., Sutriana, A., Aliza, D., Vanda, H.,dan Rahmi, E. (2010). Aktivitas Hepatoprotektif Ekstrak Etanol Daun Kucing-kucingan (Acalypha indica L.) pada Tikus Putih (Rattus novergicus) yang Diinduksi Parasetamol.Jurnal Ilmiah Ilmu-Ilmu Peternakan. 13(6): 292 - 297.

[2] Ashley,N.,J. Poulton. 2009. Mitochondrial DNA is a direct target of anticancer anthracycline drugs. Biochem. Biophys. Res. Commun. 378: 450-5.

[3] Barret, K., Brooks, H., Boitano, S., dan Barman, S. (2010). Ganong's Review of Medical Physiology. 23rd Edition. New York: McGraw Hill Companies, Inc. Hal. 479, 481-482.

[4] Bray,F.,J.Ferlay.,I.Soerjomataram.,R.L.Siegel.,L.A.Torre.,A.Jemal. 2018. Global Cancer Statistics 2018: GOBOCAN Estimates of Incidence and Mortality Worldwide for 36 Cancers in 185 Countries. CA Cancer Journal for Clinicians. 68(6): 394-424.

[5] Carvalho,C.,R.X.Santos.,S.Cardoso.,S.Correia.,P.J.Oliveira.,M.S.Santos.,P.I.Moreira. 2009. Doxorubicin: The Good, The Bad and The Ugly Effect. Current Medicinal Chemistry. 2009(16): 3267-3285.

[6] Chu, E. dan Sartorelli, A.C. (2009). Cancer Chemotherapy. Dalam buku Basic and Clinical Pharmacology. 11th Edition. International Edition. Editor: Bertram G. Katzung, Susan B. Masters, dan Anthony J. Trevor. Singapore: McGraw-Hill Medical. Hal. 951952.

[7] Cutts,S.,L.Swift.,A.Rephaeli.,A.Nudelman.,D.Phillips. 2005. Recent advances in understanding and exploiting the activation of anthracyclines by formaldehyde. Curr. Med. Chem. AntiCancer Agents. 2005(5): 431-447.

[8] Cutts,S.,P.Parsons.,R.Sturm.,D.Phillips. 1996. Adriamycin-induced DNA adducts inhibit the DNA interactions of transcription factors and RNA polymerase. J. Biol. Chem. 1996(271): 5422-5429.

[9] Danesi,R.,S.Fogli.,A.Gennari.,P.Conte.,D.M.Tacca. 2002. Pharmacokinetic pharmacodynamic relationships of the anthracycline anticancer drugs. Clin. Pharmacokinet. 2002(41): 431-444.

[10] Departemen Kesehatan RI. Dirjen POM. (1995). Materia Medika, Indonesia. Jilid VI. Jakarta : Departemen Kesehatan RI. Halaman 300.

[11] Departemen Kesehatan Republik Indonesia, Direktorat Pengawasan Obat Tradisional. (2000). Parameter Standar Umum Ekstrak Tumbuhan Obat. Jakarta: Departemen Kesehatan RI. Hal 1, 10-11

[12] Depkes RI. 2008. Farmakope Herbal Indonesia. Edisi I. Jakarta. Departemen Kesehatan Indonesia RI. Hal 122.

[13] Gruber,B.,E.Anuszewska.,W.Priebe. 2004. The effect of new anthracycline derivatives on the induction of apoptotic processes in human neoplastic cells. Folia Histochem. Cytobiol. 2004, (42): 127-130.

[14] Hadi,E.H.,R.Vettor.,M.Rossato. 2018. Vitamin E as a Treatment for Nonalcoholic Fatty Liver Disease: Reality of Myth ?. Antioxidants. 7(1): 1-12.

[15] Hasan,R.,N.Islam.,R.Islam. 2016. Phytochemistry, Pharmacological activities and Traditional Uses of Emblica officinalis: A Review. International Current Pharmaceutical Journal. 5(2): 14-21.

[16] Ismail,A.,W.A.N.W.Ahamad. 2019. Syzygium polyanthum (Wight)Walp: A Potential Phytomedicine. Pharmacogn Journal. 11(2): 429-438. 
[17] Istiqomah, 2013. Perbandingan Metode Ekstraksi Maserasi dan Sokletasi terhadap kadar Piperin Buah Cabe Jawa (Piperis retrofracti fructus). Jakarta. Fakultas Kedokteran dan Ilmu Kesehatan Universitas Islam Negeri Syarif Hidayatullah. Skripsi.

[18] Jack, 2012, Syntetis Of Antidiabetic Flavonoids and Their Derivative. Medical Research Page 180

[19] Kartikasari, D., Nurkhasanah, Suwijiyo, P. 2014. Karakterisasi Simplisia Dan Ekstrak Etanol Daun Bertoni (Stevia rebaudiana) Dari Tiga Tempat Tumbuh. Proceeding Seminar Nasional Perkembangan Terbaru Pemanfaatan Herbal Sebagian Agen Preventif Pada Terapi Kanker.. Halaman:149- 150.

[20] Kementerian kesehatan RI. 2019. Hari Kanker Sedunia 2019. Biro Komunikasi dan Pelayanan Masyarakat.

[21] King,P.D.,M.C.Perry. 2001. Hepatotoxicity of Chemotherapy. The Oncologist. 6(2): 162- 176.

[22] Kuzu, M., Yildirim, S., Kandemir, F.M., Küçűkler, S., Çağlayan, C., Tűrk, E., Dörtbudak, M.B. 2019. Protective Effect of Morin on Doxorubicin-Induced Hepatorenal Toxicity in Rats. Chemico-Biological Interactions. 308 (2019). pp 89-100.

[23] Lamas,D.J.M.,M.B.Nicoud.,H.A.Sterle.,E.Carabajal.,F.Tesan.,J.C.Perazzo.,G.A.Cremas chi.,E.S.Rivera.,V.A.Medina. 2015. Selective Cytoprotective Effect of Histamine on Doxorubicin-Induced Hepatic and Cardiac Toxicity in Animal Models. Cell Death Discovery. 1: 15059.

[24] Lelono RA, Tachibana S, Itoh K. In vitro antioxidative activities and polyphenol content of Eugenia polyantha wight grown in Indonesia. Pak J Biol Sci 2009;12:1564-70.

[25] Lelono RA. Extracts as inhibitors of key enzymes for type 2 diabetes. J Med Sci 2013;13:103-10.

[26] Lewis, P. N. (2008). Drugs and The Liver. London: Pharmaceutical Press. Hal.59-60.

[27] Lewis, A.D.; Lau, D.H.; Duran, G.E.; Wolf, C.R.; Sikic, B.I. Role of cytochrome P-450 from the human CYP3A gene family in the potentiation of morpholino doxorubicin by human liver microsomes. Cancer Res., 1992, 52, 4379-4384.

[28] Liu, L.,T.Rowe.,L.Yang.,K.Tewey.,G.Chen. 1983. Cleavage of DNA by mammalian DNA topoisomerase II. J. Biol. Chem. 258: 15365-15370.

[29] Marpaung, M.P., Ahwizar, A., dan Wulandari, W. 2017. Karakterisasi dan Skrining Fitokimia Ekstrak Kering Akar Kuning (Fibraurea chloroleuca Miers). Prosiding Seminar Nasional Kimia UNY. Halaman 145-154.

[30] Minotti, G.; Menna, P.; Salvatorelli, E.; Cairo, G.; Gianni, L. Anthracyclines: molecular advances and pharmacologic developments in antitumor activity and cardiotoxicity. Pharmac. Rev., 2004, 56, 185-229.

[31] Nirmala, M., Girija, K., Lakshman, K., dan Divya, T. (2012). Hepatoprotective Activity of Musa Paradisiaca on Experimental Animal Models. Asian Pasific Journal of Tropical Biomedicine; 2(1): 11.

[32] Padmasari, P.D., Astuti, K.W dan Warditiani, N.K. 2013. Skrining Fitokimia Ekstrak Etanol 70\% Rimpang Bangle (Zingiber purpureum Roxb.). Jurnal Farmasi Udayana. Halaman 1-7.

[33] Puspitasari, L., Swastini, D.A dan Arisanti, C.I.A. 2013. Skrining Fitokimia Ekstrak Etanol 95\% Kulit Buah Manggis (Garcinia mangostana L.). Jurnal Farmasi Udayana. Halaman 1-5. 
[34] Rizki,M.I.,E.M.Hariandja. 2015. Review: Aktivitas Farmakologis, Senyawa Aktif, dan Mekanisme Kerja Daun Salam (Syzygium polyanthum). Prosiding Seminar Nasional dan Workshop “Perkembangan Terkini Sains Farmasi dan Klinik 5”. Padang, 6-7 November 2015

[35] Saad, S.Y., Najjar, T.A., and Al-Rikabi, A.C. 2001. The preventive role of deferoxamine against acute doxorubicin-induced cardiac, renal and hepatic toxicity in rats. Pharmacol Res. (2001);43. pp 211-218.

[36] Saifudin, A., Rahayu., Teruna. 2011. Standarisasi Bahan Obat Alam. Yogyakarta. Graha Ilmu.

[37] Sangi, M.S., Momuat, L.I., dan Kumaunang, M. 2013. Uji Toksisitas dan Skrining Fitokimia Tepung Gabah Pelepah Aren (Arange pinnata). Manado: Universitas Sam Ratulangi.

[38] Sani, R.N., Fithri C.N., Ria D.A., dan Jaya M.M. 2014. Analisis Rendemen dan Skrining Fitokimia Ekstrak Etanol Mikroalga Laut Tetraselmis chuii. Jurnal Pangan dan Agroindustri. 2(2):121-126.

[39] Saragih, R. 2014. Uji kesukaan panelis pada teh daun torbangun (Coleus ambonicus). EJournal WIDYA Kesehatan dan Lingkungan, 1(1): 52.

[40] Simaremare, E.S. 2014. Skrining Fitokimia Ekstrak Etanol Daun Gatal (Laportea decumana (Roxb.) Wedd). Pharmacy. 11(1). Halaman 100.

[41] Silalahi,M. 2017. Syzygium polyanthum (Wight)Walp. (Botani, Metabolit sekunder dan Pemanfaatan). Jurnal Dinamika Pendidikan. 10(1): 1-16.

[42] Simaremare, E.S. 2014. Skrining fitokimia ekstrak etanol daun gatal (laporte decumana (Roxb.)Wedd). Pharmacy. 11(1): 98-107.

[43] Swift,L.,A.Rephaeli.,A.Nudelman.,D.Phillips.,S.Cutts. 2006. Doxorubicin-DNA adducts induce a non-topoisomerase IImediated form of cell death. Cancer Res. 66: 4863-4871.

[44] Verawati.,D.Nofiandi.,Petmawati. 2017. Pengaruh Metode Ekstraksi Terhadap Kadar Fenolat Total Dan Aktivitas Antioksidan Daun Salam. Jurnal Katalisator. 2(2): 53-60.

[45] WHO. (2000). General Guidelines for Methodologies on Research and Evaluation of Traditional Medicine. Geneva: World Health Organization.

[46] Wilapangga, A., dan Sari, L.P., 2018. Analisis Fitokima dan Antioksidan Metode DPPH Ekstrak Metanol Daun Salam (Eugenia polyantha). IJOBB. 2(1). Hal 21.

[47] Winer, E.; Morrow, M.; Osborne, C. (ed.). Malignant tumors of the breast. Cancer Princ. Pract. Oncol., 2001, 1651-1717.

[48] Yulianti, D., Susilo, B dan Yulianingsih, R .2014. Influence Of Extraction Time And Ethanol Solvent Concentration To Physical-Chemical Properties Stevia Leaf Extract (Stevia Rebaudiana Bertoni M.) Using Microwave Assisted Extraction Methods. Jurnal Bioproses Komoditas Tropis. 2(1). pp:25-31.

[49] Zainab, Sulistyani, N., dan Anisaningrum. 2016. Penetapan Parameter Standarisasi Non Spesifik dan Spesifik Ekstrak Daun Pacar Kuku (Lawsonia inermis L.). Media Farmasi; 13. Halaman 212-26.

[50] Zhao, X., Zhang, J., Tong, N., Chen, Y., Luo, Y. 2012. Protective effects of berberine on doxorubicin-induced hepatotoxicity in mice. Biol Pharm Bull. 35(5): 796-800. 